\title{
Diagnostic Utility of Microarray Testing in Chromosome Five Associated Disorders
}

\section{Beşinci Kromozom İliş̧kili Hastalıklarda Mikrodizin Analizinin Tanısal Önemi}

\author{
Haktan Bagis Erdem ${ }^{1}$, Ahmet Cevdet Ceylan ${ }^{2}$ \\ ${ }^{1}$ Sağlık Bilimleri Üniversitesi, Dr. Abdurrahman Yurtaslan Ankara Onkoloji Eğitim ve Araştırma Hastanesi, \\ Tıbbi Genetik Kliniği, Ankara, Türkiye \\ ${ }^{2}$ Yıldırım Beyazıt Üniversitesi Tıp Fakültesi, Tıbbi Genetik Anabilim Dalı, Ankara, Türkiye
}

Dergiye Ulaşma Tarihi: 26.03.2020 Dergiye Kabul Tarihi:31.03.2020 Doi: 10.5505/aot.2020.68926

\section{ÖZET}

GiRiş ve AMAÇ: Kromozomal boyutta 50 bazdan daha büyük alanı kaplayan değişikliklere kopya sayısı değişikliği (copy number variation - CNV) adı verilmektedir. Beşinci kromozom, üzerinde yerleşik genlerin fonksiyonu itibariyle farklı fenotiplerin gelişimine açık ve diğer kromozomal lokasyonlara nazaran patojenik değişikliklerin daha sık görüldüğü bir alandır. Makalemizde, bu antiteyi desteklemek amacıyla mikrodizin analizlerinde tespit edilen, beşinci kromozomda yerleşik patojenik CNV'lerin sebep olduğu bir Sotos sendromu, bir CCT5 geni ilişkili nöropati ve üç 5q14 mikrodelesyonu bildirilmiştir. YÖNTEM ve GEREÇLER: Mikrodizin çalışmaları, Affimetrix ${ }^{\circledR}$ Cytoscan Optima çipleri ile yapılıp, hasta verileri Chromosome Analysis Suite (ChAS) 3.1 Thermo Fisher Scientific ${ }^{\circledR}$ programı yardımıla analiz edildi. BULGULAR: Vaka 1, vaka 2 ve vaka 3'de, delesyonlu alanların kapsamı değişken olmakla birlikte, 5q14.3 mikrodelesyonu tespit edilmiştir. Vaka 4, NSD1 gen delesyonu ile Sotos sendromu tanısı almıştır (arr[GHCR38]5q35.2q35.3(176144147_177716919)x1). Vaka 5'in temel bulgusu kas güçsüzlüğü ve bununla iliş̧ili olarak EMG'de nöropati ile uyumlu denervasyon bulguları olup, mikrodizin analizinde CCT5 geninin delesyonu klinikle ilişkilendirilmiştir (arr[GRCh38]5p15.2(10236581_10253807)x1) (Tablo 1). TARTISSMA ve SONUÇ: Mikrodizin analizinin bu algoritmadaki yeri ve limitasyonları; sunulan vakalardaki literatürdeki yeni bulgularla beraber tartışılmışıır. Özellikle beşinci kromozomda yerleşik genlerde görülen CNV'lerin OMIM fenotipleri ile yoğun ilişskisi bu bölgeye ait hastalıkların tanısında mikrodizin analizinin önceliğini ön plana çıkarmıştır.

Anahtar Kelimeler: Mikrodizin, kopya sayısı değişikliği, beşinci kromozom.

\begin{abstract}
INTRODUCTION: Chromosomal rearrangements that cover more than 50 bases are called copy number variation $(\mathrm{CNV})$. The fifth chromosome is a position, open to the development of different phenotypes in terms of the function of the genes located on it, and pathogenic changes are more common than other chromosomal locations. To support this entity, we reported a Sotos syndrome, a CCT5 gene-related neuropathy, and three 5q14 microdeletions, detected by microarray analysis, caused by pathogenic CNVs located on the fifth chromosome. METHODS: Microarray analysis were performed with Affimetrix ${ }^{\circledR}$ Cytoscan Optima chips and patient data were analyzed with the help of Chromosome Analysis Suite (ChAS) 3.1 Thermo Fisher Scientific ${ }^{\circledR}$ program. RESULTS: Although the scope of deletion areas in case 1, case 2 and case 3 is variable, $5 \mathrm{q} 14.3$ microdeletion was detected. Case 4 was diagnosed with Sotos syndrome by deletion involving the NSD1 gene (arr [GHCR38] 5q35.2q35.3 (176144147_177716919) x1). The main finding of Case 5 is muscle weakness and denervation findings in EMG compatible with neuropathy, and in the microarray analysis, deletion of the CCT5 gene has been clinically associated (arr [GRCh38] 5p15.2 (10236581_10253807) x1) (Table 1). DISCUSSION AND CONCLUSION: The importance and limitations of microarray analysis in this algorithm have been discussed along with new findings in the literature in the presented cases. CNVs, especially in the genes located in the fifth chromosome, have a strong relationship with OMIM phenotypes, highlighting the priority of microarray analysis in the diagnosis of diseases belonging to this region.
\end{abstract}

Keywords: Microarray, copy number variation, fifth chromosome 


\section{GİRIŞ}

İnsan genomu yaklaşık üç milyar bazdan oluşmaktadır. Kromozomal boyutta 50 bazdan daha büyük alanı kaplayan değişikliklere kopya sayısı değişikliği (copy number variation - CNV) adı verilmektedir (1). Hücre döngüsü sırasında görev yapan homolog rekombinasyon ve non-homolog rekombinasyon mekanizmalarının işleyişi sırasinda söz konusu kopya sayısı değişiklikleri oluşmaktadır (2). CNV tanımı kapsaminda ilgili kromozomal lokasyonda referans genoma göre kazanım (duplikasyoninsersiyon) ya da kayip (delesyon) görülebilmektedir. Sağlıklı popülasyonda bile bir milyon baz1 kapsayan CNV'ler görülebilmekle birlikte, bazı kromozomal lokasyonlarda 50 bazlık değişimlerin dahi patojenik etki gösterebileceği bildirilmiştir (3).

Tek nokta polimorfizmleri (single nucleotide polymorphsim - SNP) ve CNV'ler bireyler arasındaki fenotipik farklılıkların ortaya çıkmasında rol oynamaktadırlar. Bunun yanında bazı CNV'ler belirli kompleks hastalıklarla ilişsilendirilmiş olup mendeliyen hastalıkların ve mikrodelesyonmikroduplikasyon sendromlarının moleküler etyopatogenezini oluşturmaktadırlar. Tanı koydurucu özelliklerine ek olarak CNV'ler aynı zamanda multifaktöryel hastalıklar için risk faktörü de olabilmektedir. Örneğin, 15q13.3 mikrodelesyon sendromu otistik spektrum bozukluğu, epilepsi ve global gelişme geriliği ile ilişkilendirilmişken; aynı bölgenin duplikasyonu şizofreni için de risk faktörü olarak tanımlanmıştır (4). Kanser yatkınlıklarının tespitinde de özellikle yanlışeşleşme tamir mekanizmasında görevli gen bölgelerine yapılan mikrodizin analizleri tanıda kullanılmaktadır (5).

Mikrodizin analizinde genom boyu analiz yapılmakla birlikte beşinci kromozom, üzerinde yerleşik genlerin fonksiyonu itibariyle farklı fenotiplerin gelişimine açık ve diğer kromozomal lokasyonlara nazaran patojenik değişikliklerin daha sık görüldüğü bir alandır. Makalemizde, bu antiteyi desteklemek amacıyla Ankara İl Sağlık Müdürlüğü Genetik Hastalıklar Değerlendirme Merkezi bünyesinde yapılan mikrodizin analizlerinde tespit edilen, beşinci kromozomda yerleşik patojenik CNV'lerin sebep olduğu bir Sotos sendromu, bir CCT5 geni ilişkili nöropati ve üç 5q14 mikrodelesyonu bildirilmiştir.

\section{GEREÇ VE YÖNTEM}

Hastalardan veya hasta velilerinden aydınlatılmış onam alındı. Etik kurul izni 2019-08/387 karar numaras1 ile Dr. Abdurrahman Yurtaslan Ankara Onkoloji Eğitim ve Araştırma Hastanesi, Klinik Araştırmalar Etik Kurulu tarafindan onaylandı. Mikrodizin çalışmaları, Ankara İl Sağlık Müdürlüğü Genetik Hastalıklar Değerlendirme Merkezi bünyesinde Affimetrix ${ }^{\circledR}$ Cytoscan Optima çipleri ile yapılıp, hasta verileri Chromosome Analysis Suite (ChAS) 3.1 Thermo Fisher Scientific ${ }^{\circledR}$ programı yardımıyla analiz edildi. Hastalardan aşağıdaki sinıflamaya göre patojenik ve olası patojenik olarak değerlendirilen değişiklikler çıkarıldı; kalan CNV'ler büyüklük, lokalizasyon, LogRD2, değeri gibi verilerin incelenmesine göre değerlendirildi.

CNV'lerin tespitinde rutinde kullanılan mikrodizin (array comparative genomic hybridisation - aCGH) yöntemi floresan boya ile işaretlenmiş hasta DNA'sına ve referans DNA'ya ait DNA fragmentlerinin hibridize edilmesi ve hibridizasyon oranının ölçülmesiyle yapılmaktadır. Dengeli translokasyonların tespit edilememesi, prob yerleşim sıklığının azaldığ CNV'ler hakkında bilgi alamama ve çalışma sırasında oluşan artefaktlar mikrodizin yönteminin sınırlamalarını oluşturmaktadır.

Analiz işlemlerinde ilk basamakta üretici firmanın önerdiği standart metot (minimum prop sayıs1 25 ve minimum büyüklük 100 kilobaz (kb)) uygulandı. İkinci basamak analizde minimum prop sayıs1 5 ve minimum büyüklük $1 \mathrm{~kb}$ olarak filtreleme değiştirilerek tekrar ChAS 3.1 programında analiz edildi.

\section{Mikrodizin Verilerin Sinıflandırılmast}

Mikrodizin verileri genel olarak üç ayrı sınıfta değerlendirilmektedir (patojenik - klinik anlamı bilinmeyen - benign) (6). Sinıflar arası değişiklik literatürün ve veritabanlarının güncellenmesine göre aile segregasyonun öğrenilmesine göre değişiklik gösterebilir. Bu yüzden özellikle klinik önemi bilinemeyen değişikliklerin bir-iki yıl sonra tekrar değerlendirilmesi önerilmektedir.

Adress for correspondence: Uzm. Dr. Haktan Bagis Erdem Dr. Abdurrahman Yurtaslan Ankara Onkoloji Eğitim ve Araştırma Hastanesi, Tibbi Genetik Kliniği 06200 Ankara - Türkiye 
Patojenik değişiklikler, hastanın fenotipi ile ilişsili düşünülen, literatürde daha önce gösterilmiş olan değişikliklerdir. $\mathrm{Bu}$ gruptaki CNV'ler genellikle de novo olarak görülmekle birlikte parenteral kalıtım da gözlenebilir. Patojenik değişiklikler üç alt kısımda sinıflandırılabilir.

Birinci kısımda sinıflanan patojenik değişiklikler, $5 \mathrm{Mb}$ 'dan büyük değişikliklerdir. $\mathrm{Bu}$ grup değişiklikler kromozom analizi ile de görülebilen, çok sayıda gen içeren, içerdiği bölgedeki daha küçük delesyonları veya duplikasyonları kesin fenotiple ilişkilendirilmiş olan değişikliklerdir. Benzer fenotiple hastalar bildirilmiş olsa da gen içeriği fazla ve farklı olduğu için bu değişikliklerde farklı fenotipik özellikler görülemeyebilir. Doğrulama ve aile segregasyonu gerekmez. Williams Sendromu, $4 \mathrm{p}$ delesyon sendromu, $1 \mathrm{p} 36$ delesyon sendromu gibi sendromlar bu gruba örnektir.

İkinci kısımda sinıflanan 5 Mb'dan küçük patojenik değişiklikler ise literatürde tanımlanmış delesyon ve duplikasyonları içerir. Veritabanlarında ilk gruptaki kadar çok olmasa da çok sayıda hasta bildirilmiştir. Sağlıklı toplum veritabanlarında bu bölge değişikliği yoktur ya da çok az sayıdadır (değişken ekspresivite nedeniyle hafif fenotip gösterebilirler). $\mathrm{Bu}$ grup değişikliklerin başka bir yöntemle doğrulanması ve aile segregasyonun araştırılması gereklidir. $\mathrm{Bu}$ değişiklikler patolojik olarak raporlanırken literatür desteği özellikle belirtilmelidir. $15 \mathrm{q} 13.3$ delesyonu, 16p11.2 delesyonu, 22q11.2 duplikasyonu bu gruba örnektir.

Üçüncü kısım, olası patojenik değişiklikler olup CNV'nin içerdiği genler bakımından önemli olabilecek ancak az sayıda literatür desteğinin olduğu değişikliklerdir. Sağlıklı toplum veritabanında az sayıda bu bölgeyi kapsayan değişiklik bildirilmiştir. Tek nokta değişikliklerinin hastalıkla ilişkisi fonksiyon kaybı ile açıklanmış genlerdeki delesyonlar bu grupta sinıflandirılabilir. Ayrica bilinen bazı delesyon sendromlarının duplikasyonları nörogelişimsel hastalıklar için risk faktörü olarak bildirildiği için bu grupta değerlendirilebilir. 15q13.3 duplikasyonu ya da nörogelişimsel fonksiyonu olan gen delesyonları bu gruba örnektir.

Klinik anlamı bilinmeyen değişiklikler ise literatür desteği yeterli olmayan, ancak veritabanlarında az sayıda sağliklı ve hasta verisi bildirilmiş durumlardır. $\mathrm{Bu}$ grup da kendi içinde 3 kısımda değerlendirilirilebilir.

Klinik anlamı bilinmeyen/olas1 patojenik grup, patojenitesi için yeterli kanıt olmayan ancak gen içeriği ve klinikle uyumu bakımından patojenite ihtimali olanları kapsar.

Klinik anlamı bilinmeyen grup, patojenite ya da benignlik yönünden sinıflanamayan genelde literatür bilgisinin ve veritabanı bilgisinin olmadığı gruptur.

Klinik anlamı bilinmeyen/olası benign grup ise ailede benzer değişikliği gösteren ve klinik bulgusu olmayan grubu kapsar, değişiklikler ailesel olabileceği düşünülmekle birlikte benign demek için yeterli sağlıklı bilgisi veritabanlarında henüz yoktur.

Benign değişiklikler, içerdiği genlerin fonksiyonu ve sağlıklı toplum veritabanlarında sık görüldüğü için fenotiple ilişkilendirilmeyen değişikliklerdir. Genellikle anne veya babadan kalıtılırlar. Bazı benign CNV'ler coğrafik bölgelere özgü olması nedeniyle yerel veritabanlarında uluslararası veritabanlarından daha sik görülebilir. Benign CNV'ler veritabanlarında görülme sıklığına göre sınıflandırılabileceği gibi bu sınıflandırmanın pratikte yararı çok fazla değildir. Ancak bir veritabanındaki değişikliğin anlamlı kabul edilmesi için ikiden fazla bağımsız çalışmada farklı bireylerde saptanmış olması gereklidir (7).

Benign CNV'ler hasta veritabanlarında da bildirilmiş olabilir. Çünkü hasta verisi saklayan veritabanlarındaki bütün değişiklikler fenotiple ilişkili değildir. Fenotipik bulguları olan bireylerin genotiple ilişkilendirilmeksizin saklanması, ayn1 hastada patojenik bir değişiklikle birlikte bulunan benign CNV'ler de bildirildiği için karışıklığa neden olabilir. Sağlıklı toplum veritabanlarında çok sayıda görülen bir CNV'nin hasta veritabanlarında az sayıda hastada da bildirilmiş olması olağan olarak değerlendirilmelidir.

\section{BULGULAR}

Üç hastada 5q14.3 mikrodelesyonu tespit edilmiştir (Tablo 1). Vaka 1'de 556 kb delesyon

(arr[GRCh38]5q14.3(88647050_89203364)x1) vaka 2'de $4855 \quad \mathrm{~kb}$ delesyon (arr[GHCR38]5q14.3q15(88869316_93725075 )x1), vaka 3'de $5134 \quad \mathrm{~kb}$ delesyon (arr[GHCR38]5q13.3q14.1(76293196_814276

Adress for correspondence: Uzm. Dr. Haktan Bagis Erdem Dr. Abdurrahman Yurtaslan Ankara Onkoloji Eğitim ve Araştırma Hastanesi, Tıbbi Genetik Kliniği 06200 Ankara - Türkiye e-mail: haktanbagis@gmail.com 
39)x1) tespit edilmiştir. Düzeyleri değişkenlik göstermekle birlikte her üç vakada da bilişsel gelişme geriliği bulgusu ortaktır. Santral sinir sistemi bulgularından farklı olarak sadece vaka 3 'de primer immün yetmezlik tanısı mevcuttur.

Vaka 4'e global gelişme geriliăgi, makrosefali, dismorfik yüz bulguları, epilepsi ve EKO'da pulmoner stenoz bulguları sebebiyle mikrodizin analizi uygulanmış, analiz sonucunda NSDl genini içine alan delesyon tespit edilen hasta Sotos sendromu tanis1 almıștır (arr[GHCR38]5q35.2q35.3(176144147_17771 6919)x1) (Tablo 1).

Vaka 5'in temel bulgusu kas güçsüzlügü ve bununla ilişkili olarak EMG'de nöropati ile uyumlu denervasyon bulguları olup, fizik muayenesinde derin tendon refleksleri alınamamıştır. Yapılan psikiyatrik değerlendirmede metal gelişimi, sınırda zeka düzeyinde saptanmıştır. Mikrodizin analizinde CCT5 geninin delesyonu klinikle ilişkilendirilmiştir

(arr[GRCh38]5p15.2(10236581_10253807)x1)

(Tablo 1).

Tablo 1. Vakalarin genotip ve fenotip özellikleri

\begin{tabular}{|c|c|c|c|}
\hline Vaka & Tanı & $\begin{array}{c}\text { Mikrodiz } \\
\text { in } \\
\text { bulgusu }\end{array}$ & $\begin{array}{c}\text { Klinik } \\
\text { bulgular }\end{array}$ \\
\hline 1 & $\begin{array}{c}5 \mathrm{q} 14 \\
\text { mikrodele } \\
\text { syonu }\end{array}$ & $\begin{array}{c}\operatorname{arr}[\mathrm{GRCh} \\
38] 5 \mathrm{q} 14.3 \\
(8864705 \\
0 \_892033 \\
\text { 64)x1 }\end{array}$ & $\begin{array}{l}\text { Hafif-orta } \\
\text { BGG }^{1} \\
\text { Epilepsi }\end{array}$ \\
\hline 2 & $\begin{array}{c}5 \mathrm{q} 14 \\
\text { mikrodele } \\
\text { syonu }\end{array}$ & $\begin{array}{c}\operatorname{arr}[\mathrm{GHC} \\
\mathrm{R} 38] 5 \mathrm{q} 14 \\
.3 \mathrm{q} 15(888 \\
69316 \_93 \\
725075) \mathrm{x} \\
1\end{array}$ & $\begin{array}{l}\text { Ağır BGG }{ }^{1} \text {, } \\
\text { Korpus } \\
\text { kallozum } \\
\text { hipoplazisi, } \\
\text { Epilpesi, } \\
\text { Dismorfik } \\
\text { bulgular }\end{array}$ \\
\hline 3 & $\begin{array}{c}5 \mathrm{q} 14 \\
\text { mikrodele } \\
\text { syonu }\end{array}$ & $\begin{array}{c}\operatorname{arr}[\mathrm{GHC} \\
\mathrm{R} 38] 5 \mathrm{q} 13 \\
.3 \mathrm{q} 14.1(7 \\
6293196 \\
81427639 \\
) \mathrm{x} 1 \\
\end{array}$ & $\begin{array}{l}\text { Hafif BGG }{ }^{1} \text {, } \\
\text { İmmün } \\
\text { yetmezlik, } \\
\text { Epilpesi, } \\
\text { Konuşmada } \\
\text { gecikme }\end{array}$ \\
\hline 4 & $\begin{array}{c}\text { Sotos } \\
\text { sendromu }\end{array}$ & $\begin{array}{c}\operatorname{arr}[\mathrm{GHC} \\
\mathrm{R} 38] 5 \mathrm{q} 35 \\
.2 \mathrm{q} 35.3(1 \\
76144147 \\
-1777169 \\
19) \times 1\end{array}$ & $\begin{array}{l}\text { Orta düzey } \\
\text { GGG }^{2}, \\
\text { Epilepsi, } \\
\text { Pulmoner } \\
\text { stenoz, } \\
\text { Dismorfik } \\
\text { bulgular, } \\
\text { Makrosefali }\end{array}$ \\
\hline
\end{tabular}

\begin{tabular}{|c|c|c|l|}
\hline \multirow{5}{*}{5} & CCT5 & arr[GRCh & Sinırda zeka, \\
Kas \\
& geni & 38]5p15.2 & güçsüzlüğü, \\
& ilişkili & $(1023658$ & EMG de \\
nöropati & $1 \_102538$ & nöropati, \\
& & $07) \times 1$ & DTR $^{3}$ kayb 1 \\
\hline
\end{tabular}

\section{TARTIŞMA}

Nadir hastalıklar gittikçe önem kazanmakla birlikte, son dönemde ülkemizde de bu tür hastalıklara profesyonel yaklaşım konusunda sosyal, bilimsel ve idari-bürokratik anlamda altyapı oluşturma çabası mevcuttur. Dünya'da yaklaşı 350 milyon kişiyi etkileyen nadir hastalıkların \%80'inin genetik hastalıklar oluşturmaktadır. Nadir hastalıklar açısından tanı koyma süresi ortalama 4.8 yıl olmakla birlikte bu grup hastalıkların sadece \%50'sine tanı konabilmektedir $(8,9)$.

Mikrodizin analizi tespit edebildiği nadir hastalıklar açısından, tanı koyma başarısı ve maliyet-etkinliği ile rutin tan1 basamaklarında önemli bir yer tutmaktadır. Bu makalenin amacı mikrodizin analizinin, nadir rastlanan beşinci kromozom değişikliklerinin yol açtığ 1 klinikleri tartışmak ve mikrodizin yönteminin 5q14.3 mikrodelesyonu ve Sotos sendromu gibi sendromların tanısına ek olarak herediter nöropati kliniğinin açıklanmasında kullanılabileceğinin gösterilmesidir. Tek gen hastalıkları, büyük ölçüde dizi analizi yöntemi ile tanı alabilse de hastalığa sebep olan genomik değişikliklerin \%10'dan az bir kısmı dizi analizinin çoğunlukla tespit edemediği CNV'ler zemininde gerçekleşmektedir. Her ne kadar biyoinformatik araçlar aynı çalışma içerisindeki örneklerin genomik datasının okuma derinliği değerlerinin karşılaştırılması üzerinden CNV analizi yapmaya imkan sağlasa da, bu yöntemin hassasiyeti düşük olmakla birlikte elde edilen sonuçların mikrodizin veya MLPA (multiplex ligation-dependent probe amplification) yöntemi ile doğrulanması şarttır.

5q14.3 mikrodelesyon sendromunda fenotipin ortaya çıkmasına etkisi olan gen $M E F 2 C$ genidir. Vakalar genellikle global gelişme geriliği, stereotipik hareketler ve epilepsi ile başvurmaktadır (10). Çalışmamızda tespit edilen vakaların fenotipik farklılıklarında delesyonun kapsamına giren genlerin fonksiyonu temel rolü oynamaktadır. Vakaların ortak bulgusu olan global gelişme geriliği şiddetindeki değişkenliğin de yine delesyonlu bölge içeriklerinin farklılık 
Orijinal Makale

göstermesinden

kaynaklı

olduğu

düşünülmektedir.

Vaka 3'de rapor edilen primer immün yetmezlik tablosuna sebep olma ihtimali olan tek gen AP3B1 genidir. DECIPHER veritabanında şimdiye kadar vaka 3'de görülen delesyonlu bölgedeki genlerin heterozigot delesyonlarında immün yetmezlik kliniği bildirilmemiştir (11). AP3B1 geninin homozigot mutasyonları Hermansky-Pudlak sendromuna yol açmaktadır. Vaka 3'e mikrodizin analizinden önce yapılan klinik ekzom dizileme analizinde $A P 3 B 1$ geninde, tüm gendeki heterozigot delesyonla birleşik heterozigosite zemininde Hermansky-Pudlak sendromu fenotipi oluşturacak ikinci bir aday patojenik veya olası patojenik varyasyon tespit edilmiştir. Ayrica dizileme analizine ait verinin, aynı çalışmaya ait kontrol örneklerine ait verilerle, IGV (Integrative Genomics Viewer) programı üzerinden okuma derinliğinin kıyaslanmasına dayalı CNV analizinin de söz konusu delesyonu valide ettiği görülmüştür. Sonuç olarak, HermanskyPudlak sendromunun tamamen dişlandığ 1 hastada, 5q14.3 mikrodelesyonunda primer immün yetmezlik bulgusu daha önce bildirilmemiş, yeni bir bulgudur. $\mathrm{Bu}$ durum ayrıca genetik kökenli nadir hastalıklara yaklaşımda, tanı basamakları arasında mikrodizin analizinin önemini bir kez daha ortaya çıkarmıştır.

Sotos sendromu karakteristik yüz bulguları ve öğrenme güçlüğü ile beraber görülen bir aşırı-büyüme (overgrowth) sendromudur (12). Diğer tek gen hastalıklarından farklı olarak Sotos sendromunda mikrodizin analizi \%50'ye varan oranda tanı koydurucu olabilmektedir (13). Vaka 4'de bildirilen makrosefali, gelişme geriliği ve orta düzey bilișsel gerilik Sotos sendromu kliniği ile uyumluluk göstermektedir (Tablo 1). Buradan hareketle Sotos sendromu ön tanılı hastalarda tek gen analizine ek olarak mikrodizin analizi ya da MLPA yöntemleriyle CNV analizinin önemli olduğu görülmektedir.

Vaka 5'de CCT5 geninde heterozigot tüm gen delesyonu tespit edilmiştir. CCT5 geninin homozigot mutasyonları, OMIM (online Mendelian inheritance in man) veritabanında CCT5 spastik parapleji ve herediter duyusal nöropati ile ilişkilendirilmiştir. Vaka 5'de kliniği açıklayan başka CNV bulunmaması sebebiyle, söz konusu CNV'nin fenotiple ilişkili olabileceği düşünülmüsstür. Vaka 5'e yapılan ebeveyn taramasinda CCT5 geninin normal olması da, de novo gelişen nöropati bulgusunu desteklemektedir. $\mathrm{Bu}$ durumda mikrodizin analizinden elde edilen CNV'lere segregasyon analizi yapılmasının önemi anlaşılmaktadır. Özellikle kliniğin mevcut verilerle anlaşılamadığı durumlarda, elde edilen şüpheli CNV'lerin sağlıklı bir şekilde yorumlanması ebeveynlere yapılacak mikrodizin analizleri ile mümkündür.

Genetik testlerin kullanımı her geçen gün yaygınlaşmakta ve tanı sistemleri de kendi içerisinde gün geçtikçe gelişmektedir. Tanı yöntemlerinin maliyet-etkinlik politikasına uygun bir şekilde etkin kullanımı, nadir hastalıklara doğru ve hızlı tanı konmasını sağlayacaktır. Mikrodizin analizinin bu algoritmadaki yeri ve limitasyonları; sunulan vakalardaki literatürdeki yeni bulgularla beraber tartışılmıştır. Özellikle beşinci kromozomda yerleşik genlerde görülen CNV'lerin OMIM fenotipleri ile yoğun ilişkisi bu bölgeye ait hastalıkların tanısında mikrodizin analizinin önceliğini ön plana çıkarmıştır.

\section{REFERANSLAR}

1. Zarrei M, MacDonald JR, Merico D, Scherer SW. A copy number variation map of the human genome. Nat Rev Genet. 2015;16(3):172.

2. Hastings PJ, Lupski JR, Rosenberg SM, Ira G. Mechanisms of change in gene copy number. Nat Rev Genet. 2009;10(8):551.

3. Nussbaum RL, McInnes RR, Willard HF. Thompson \& Thompson genetics in medicine e-book: Elsevier Health Sciences; 2015.

4. Jähn JA, von Spiczak S, Muhle H, Obermeier $\mathrm{T}$, Franke A, Mefford $\mathrm{HC}$, et al. Iterative phenotyping of $15 q 11.2,15 q 13.3$ and $16 \mathrm{p} 13$. 11 microdeletion carriers in pediatric epilepsies. Epilepsy Res. 2014;108(1):109-16.

5. Bahsi T, Guntekin-Ergun S, Ergun MA, Percin EF. Comparison of the Diagnostic Accuracy of Next Generation Sequencing and Microarray Resequencing Methods for Detection of BRCA 1 and BRCA 2 Gene Mutations. GMJ. 2018;29(2):116-8.

6. Srebniak MI, Diderich KE, Govaerts LC, Joosten M, Riedijk S, Galjaard RJH, et al. Types of array findings detectable in cytogenetic diagnosis: a proposal for a generic classification. Eur J Hum Genet. 2014;22(7):856-8.

7. Riggs E, Church D, Hanson K, Horner V, Kaminsky E, Kuhn R, et al. Towards an

Adress for correspondence: Uzm. Dr. Haktan Bagis Erdem Dr. Abdurrahman Yurtaslan Ankara Onkoloji Eğitim ve Araştırma Hastanesi, Tibbi Genetik Kliniği 06200 Ankara - Türkiye e-mail: haktanbagis@gmail.com

Available at www.actaoncologicaturcica.com

Copyright $\odot$ Ankara Onkoloji Hastanesi 
evidence-based process for the clinical interpretation of copy number variation. Clin Genet. 2012;81(5):403-12.

8. Köken AH, Hayırlıdağ M, Büken NÖ. Sağlık Hakkı Bağlamında Nadir Hastalıklar ve Yetim İlaçlar. Turkiye Klinikleri J Med Ethics Law Hist-Special Topics. 2018;4(1):91-8.

9. Boycott KM, Hartley T, Biesecker LG, Gibbs $\mathrm{RA}$, Innes AM, Riess $\mathrm{O}$, et al. A diagnosis for all rare genetic diseases: the horizon and the next frontiers. Cell. 2019;177(1):32-7.

10. Engels $\mathrm{H}$, Wohlleber E, Zink A, Hoyer J, Ludwig KU, Brockschmidt FF, et al. A novel microdeletion syndrome involving 5q14. 3-q15: clinical and molecular cytogenetic characterization of three patients. Eur J Hum Genet. 2009;17(12):1592-9.
11. Firth HV, Richards SM, Bevan AP, Clayton S, Corpas M, Rajan D, et al. DECIPHER: database of chromosomal imbalance and phenotype in humans using ensembl resources. Am J Hum Genet. 2009;84(4):524-33.

12. Cole T, Hughes H. Sotos syndrome: a study of the diagnostic criteria and natural history. J Med Genet. 1994;31(1):20-32.

13. Baujat G, Cormier-Daire V. Sotos syndrome. Orphanet J Rare Dis. 2007;2(1):36. 